\title{
ACRL programs in New York
}

\section{This year's conference programs feature subject access to nonbook materials, rare books in the arts, and end user searching.}

\section{Anthropology and Sociology Section}

ANSS will sponsor a panel discussion entitled: "Images and Views: Retrieving Information from Photographs" (Sunday, June 29, 2:00-4:00 p.m.). Panelists will include: Fred Miller, curator of urban archives, Temple University, and co-author of the photographic essay, Still Philadelphia; Debora Willis-Ryan, Special Collections, Schomburg Center, New York, and author of Black Photographers, 1840-1940: A Bio-Bibliography; and Richard Chalfen, associate professor of anthropology at Temple University and specialist in culture and communication and visual anthropology. They will discuss the following questions: What kinds of unique information are available in visual resources and how do you use them? How are visual resources such as photographs, slides and videotapes organized? How does the librarian help scholars locate and use these materials? What special problems do visual resources pose for the curator? The discussion will be followed by questions from the floor and a brief membership meeting.

ANSS will also sponsor a tour of the Heye Foundation's Museum of the American Indian. The tour will include a visit to the Museum (Broadway at 155th St.) as well as to the Museum's library in the Bronx, and will conclude with a reception and light refreshments (Tuesday, July 1, 1:00-6:00 p.m.). Registration for the tour will be limited and there will be a fee of $\$ 10.50$ to cover the rental of a bus to transport the group. To register, contact Janet Steins, Chemistry Librarian, 215 Graduate Chemistry, SUNY-Stony Brook, Stony Brook, NY 11794-3425, by June 6 .

ANSS members may also wish to visit the Robert
Goldwater Library at the Metropolitan Museum of Art at 7:30 p.m., Tuesday evening. The Goldwater Library specializes in primitive art, and has a picture collection in addition to monographic and periodical holdings. The museum and its restaurant will be open that evening. If you plan to visit the library, please contact Janet Steins (address above).

\section{Art Section}

"Databases for the Arts" (Monday, June 30, 9:30 a.m. $-12: 30$ p.m.), cosponsored by the ACRL Cinema Librarians Discussion Group, will provide a sampling of databases in music, dance, theater, the visual arts, film and television, and architecture. Speakers include: Ann Bevilacqua, Columbia University; Linda Sachs, on the Arts \& Humanities $\mathrm{C} i$ tation Index; Terence Ford, on the Repertoire International de Litterature Musicale; James Monaco, on the Baseline film and TV database; and James Kopp, on the Avery Index to Architectural Periodicals.

\section{Asian and African Section}

"Asian and African Collections in American Libraries: Meeting the Research Needs for Area Studies" (Monday, June 30, 9:30 a.m.-12:30 p.m.), cosponsored by the ALA International Relations Round Table and the RTSD CCS Committee on Cataloging Asian and African Materials, will explore the role, function, strength, expertise, service, and processing of these special collections. Speakers will include Doris M. Hull, Howard University; Karl K. Lo, University of Washington; 
Charles Bryant, Yale University; Merry L. Burlingham, University of Texas; John A. Eilts, University of Michigan; and Warren M. Tsuneishi, Library of Congress.

\section{Audiovisual Committee}

"New Directions in Subject Access to Nonbook Materials" (Saturday, June 28, 9:30 a.m.-12:30 p.m.), cosponsored by the RTSD Audiovisual Committee, the RTSD CSC Subject Analysis Committee, and the ACRL RBMS Standards Committee, will focus on systems that integrate subject access to books and non-print media, and other systems developed for specific media such as prints and photographs, films, and music. Speakers are: Susan Nesbitt, Hennepin County Government Center; Elisabeth Betz Parker, Library of Congress; Donald Bidd, National Film Board of Canada; Brad Young, University of Illinois; and Karen Markey, OCLC.

\section{Bibliographic Instruction Section}

"Bibliographic Instruction for the Future: A Critical Look As We Leap" (Sunday, June 29, 2:00-5:30 p.m.) will feature Carla J. Stoffle, Uni- versity of Michigan, on "Facing the Future with a View of the Past"; Patricia D. Arnott, University of Delaware, on computer assisted instruction; and Thomas T. Surprenant, Queens College, on three future scenarios.

\section{College Libraries Section}

"Profound Changes/Profound Reflections" (Saturday, June 28, 9:30 a.m.-12:30 p.m.) will provide attendees with the opportunity to view a computer-assisted decision process in order to stimulate clear thinking about personal and job possibilities. The Decision Techtronics Group, of the Rockefeller College of Public Affairs and Policy, SUNY-Albany, will lead a panel of four college librarians into making a decision concerning contemporary organizational and technological innovations.

\section{Community and Junior College Libraries Section}

"New Technology-New Leadership: Opportunities for Learning Resources Faculty I" (Sunday, June 29, 2:00-5:30 p.m.) will examine the challenges, opportunities and pitfalls that lie ahead for

\section{The ACRL President's Program}

ACRL's 1986 program meeting will be held 2:00-5:30 p.m., June 30, 1986, at the New York University Loeb Student Center's Eisner-Lubin Auditorium, 566 La Guardia Place, in Greenwich Village. The program will allow ACRL members to share a common experience by which they can consider "Life on the Technology Express"- a case study set on the campus of fictitious Garfield University.

The latest controversy to engulf the Garfield University campus since the inauguration last January of President Wiley Dyer stems from Dyer's declaration of his intention to reorganize virtually all of Garfield's operations according to his belief that the university is an information processor. He wants to assign each university function to one of five groups: input, storage, processing, control, or output.

This idea has brought sharp attacks from certain staff members at Garfield's Heathcliff Library who claim that their unit is being misrepresented or even punished for being "low tech." The most vocal people in this controversy are Ely Berrien, director of the Heathcliff Library for 18 years; Irwin B. Moxie, head of the Garfield University Computing Center; state representative and Garfield trustee Katherine Kaufman; Mr. A. Keen Buch, assistant director for public services in Heathcliff $\mathrm{Li}$ brary; Minnie Roebuck, head of cataloging and chair of the Director's Executive Panel on Technol- ogy (DEPOT); and Terry Cloethe, a typical Garfield student.

Participants in the President's Program will be asked to visualize the recent history and air of controversy pervading the Garfield campus, and they will be asked to decide the future of Garfield University next June 30 . Will it survive as a traditional entity or become just another node in the information network on campus?

Participants will receive a packet of documents in advance of the program. These documents include a cast of characters, a chronology, Wiley Dyer's article ("Rethinking the Academic Library") adumbrating recent changes in the organization, memos and position papers responding to Dyer's article, and other policy/procedure memos pertaining to Garfield University and technology.

The program will include an introduction by ACRL President Sharon A. Hogan; an overview of the case study method; an address on technological implications; analyses of the case in small group discussions with library leaders; reports of discussions; and closing reflections.

Pre-registration by June 1, 1986, is necessary and attendance is limited to the first 350 people who register. No fees will be charged. To register, use the Registration Form on page 269 of the April 1986 issue of C\&RL News.

Register now, and ensure your place in "Life on the Technology Express."-Sarah Watstein. 


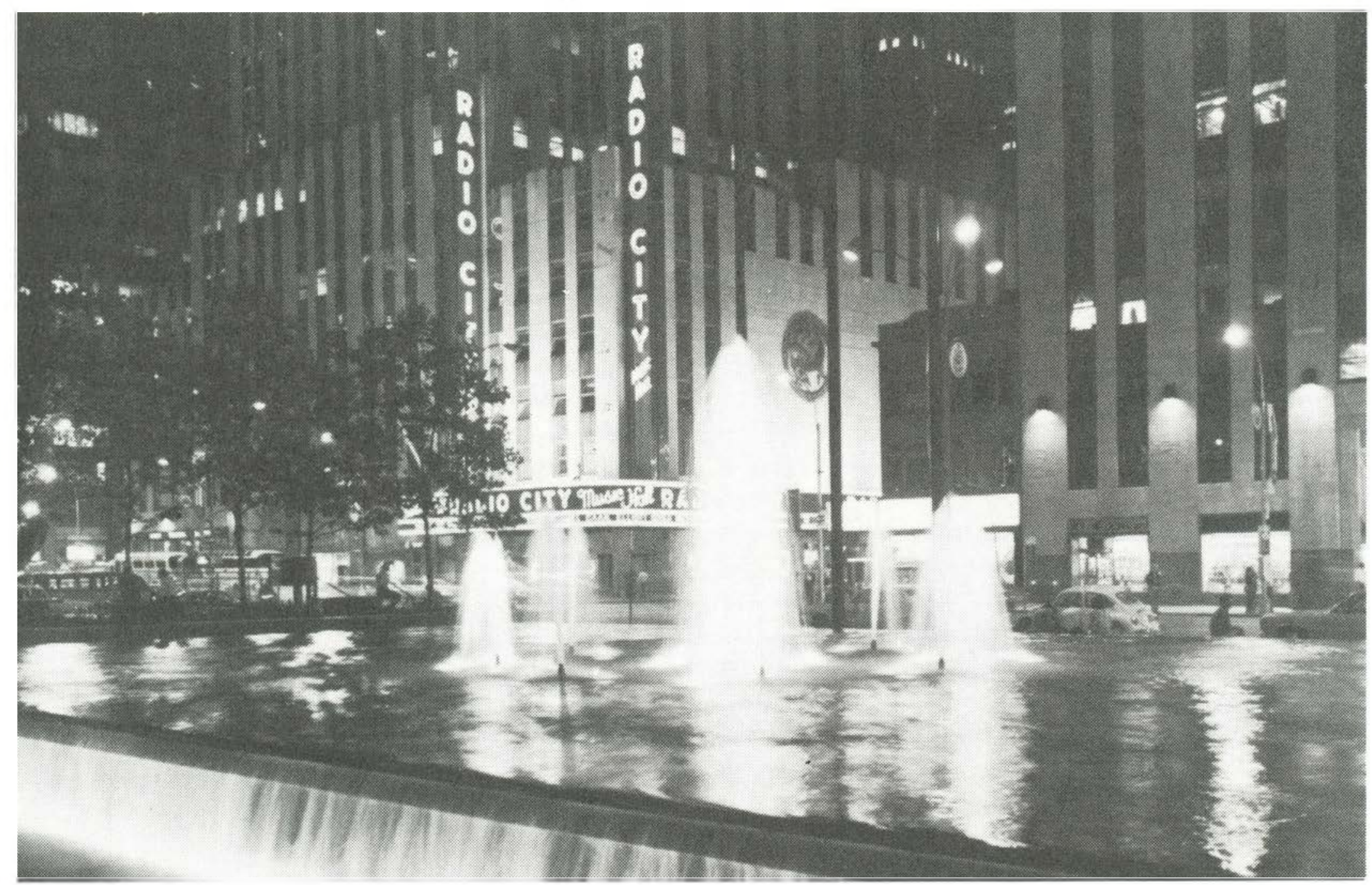

Radio City Music Hall, in Rockefeller Center on the Avenue of the Americas, is the world's largest indoor movie theater.

learning resources faculty from the perspectives of a practitioner, a sociologist, and an educational administrator. Speakers will be: Albert Donor, Nassau Community College; Donald Ely, ERIC Clearinghouse on Information Resources; and Gloria Terwilliger, Northern Virginia Community College.

CJCLS will also host a combination tour, panel, and luncheon program as Part II of its "New Technology-New Leadership" program (Monday, June 30, 8:15 a.m.-2:00 p.m.). The Kingsborough Community College campus on Manhattan Beach in Brooklyn will provide the backdrop for a discussion moderated by Robert Ford, Medgar Evers College. Scheduled speakers are: Ngozi Agbim, LaGuardia Community College; Annette Peretz, Bronx Community College; and Margaret Holleman, editor of Community and Junior College Libraries. Buses will depart at 8:15 p.m. from a headquarters hotel and return at 2:00 p.m. to the site of the ACRL President's Program. The fee for this portion of the CJCLS program is $\$ 22.50$. Reservations should be sent to Leonard Grundt, Nassau Community College Library, Stewart Avenue, Garden City, NY 11530, by June 15.

\section{Education and Behavioral Sciences Section}

"New Developments in Access to Tests" (Monday, June 30, 9:00 a.m.-12:30 p.m.) will consider the major test-related issues currently facing librarians in psychology/psychiatry and education libraries as well as in general academic reference de- partments, and will present effective strategies for reference service to test users, including the reference interview, ethical and legal considerations, major printed reference sources, and major online databases. Robert Jordan, University of Iowa, will discuss what constitutes a central core of test materials that should be in most academic and large public school systems' staff libraries. James V. Mitchell, The Buros Institute of Mental Measurements at the University of Nebraska, will discuss the Mental Measurements Yearbooks and the Buros Institute's online database. Mary G. McMahon, BRS Information Technologies, will focus on the online environment and demonstrate effective search strategies. The EBSS Psychology/Psychiatry Committee will distribute a bibliography entitled, "Where to Go When Buros Won't Help."

\section{Fee-Based Information Service Centers in Academic Libraries Discussion Group}

"Look before You Leap: Preliminary Considerations for Establishing a Fee-Based Reference Service" (Monday, June 30, 9:00-11:00 a.m.), cosponsored by the RASD Fee-Based Reference Services Committee and the RASD MARS Costs and Financing of Machine-Assisted Reference Committee, will examine the circumstances that lead to a consideration of instituting fee-based services. Speakers will include: Marilyn Gell Mason, director of the Atlanta-Fulton Public Library; Mary Grant, manager of the Center for Business Research at Long Island University; and Jerome Lom, Illinois Institute of Technology. 


\section{Heads of Public/Readers' Services Discussion Group}

"The Role of Public Services in the Design of Automated Services" (Sunday, June 29, 4:30-5:30 p.m.).

\section{Law and Political Science Section}

"Issues in Providing Legal Information to NonLawyers" (Sunday, June 29, 2:00-4:00 p.m.), cosponsored by GODORT, will be a panel discussion focusing on how non-law librarians can respond to legal reference questions. Panel members are: Glen Peter Ahlers, Washburn University; Vivian Campbell, Georgetown University; Robin Mills, Emory University; and Maria Sekula, Social Law Library. They will discuss selecting a core collection of legal sources, ethical and legal considerations in providing information, and the outreach activities of the American Association of Law Libraries' Legal Information to the Public Committee. A reception sponsored by Brodart will follow from 4:00-6:00 p.m.

\section{Library Research Round Table}

ACRL is cosponsoring with LRRT a program on "Linking Theory with Practice: The CLR Faculty/ Librarian Cooperative Research Program" (Sunday, June 29, 2:00-4:00 p.m.). Faculty-librarian teams who received grants from the Council on Library Resources PETREL program will present their research findings. Participants include Kathleen Heim, Deanna Marcum, Cerise Oberman, George D'Elia, Mary Fetzer, Patricia Reeling, Dan O'Connor, Merrily Taylor, Barbara Moran, Sheila Creth, Ron Powell, and David Kohl.

\section{Personnel and Staff Development Officers Discussion Group}

"Staff Development: Practical Approaches to Getting Started" (Sunday, June 29, 9:30 a.m.-12:30 p.m.), cosponsored by the LAMA Staff Development Committee and the ALA Junior Members Round Table, will cover gaining administrative support for staff development, assessment and planning, and identifying resources. Speakers include: Barbara Von Wahlde, SUNY-Buffalo; Peggy O’Donnell, private consultant; Ann Lipow, University of California, Berkeley; and Maureen Sullivan, Yale University.

\section{Professional Association Liaison Committee}

To encourage academic librarians to become actively involved in non-library professional associations, a panel of librarians (Sunday, June 29, 9:30-11:00 a.m.) will describe their experiences and success. Each member of the panel has participated in the program of a non-library association.
Committee chair Joan Chambers, Colorado State University, will explain how interested librarians can apply to ACRL for financial assistance.

\section{Professional Education Committee}

"What's It Like to be an ACRL Trainer? An Open Forum for Potential Instructors" (Sunday, June 29, 2:00-4:00 p.m.), cosponsored by the ACRL Continuing Education Courses Advisory Committee, will focus on the need for additional trainers to present ACRL's continuing education programs. Individuals who have a particular interest in the training process and a background in education are particularly encouraged to attend.

\section{Rare Books and Manuscripts Section}

"Utilizing Rare Books in the Arts" (Sunday, June 29, 2:00-4:00 p.m.) will demonstrate the uses of rare books in New York City collections dealing with the arts. Parmenia Migel Ekstrom, dance historian and collector, will speak on how historic dance books preserve the dance of the past and influence the development of new dance forms. Robert Kaufman, librarian of the Costume Institute of the Metropolitan Museum of Art, will discuss conducting costume and fashion research from rare books and periodicals.

RBMS will also cosponsor with the ALA/SAA Joint Committee on Archives/Library Relationships a program on "The Use of the USMARC Format for Archival and Manuscripts Control" (Saturday, June 28, 2:00-4:00 p.m.). The program will provide an introduction to the USMARC/AMC format, discuss its use and interpretation, and describe the application of standards used in conjunction with it. Speakers will be: Katherine D. Morton, Yale University; Nancy A. Sahli, National Archives and Records Administration; and Steven L. Hensen, Library of Congress.

\section{Research Discussion Group}

"Research Clinic II: Designing a Research Study” (Monday, June 30, 8:30 a.m.-12:30 p.m.) will aid novice researchers in developing a basic framework for carrying out a research study. Participants will be guided through the design by experienced researchers. The scheduled speaker is Trudi Bellardo, School of Library and Information Science, University of Kentucky.

\section{Science and Technology Section}

“End User Searching: Issues in Instruction, Systems Selection, and Administration" (Tuesday, July 1, 9:00 a.m.-12:30 p.m.), cosponsored by the ACRL BIS Computer Concerns Committee and the RASD MARS Direct Patron Access Committee, will provide an opportunity to participate in group discussions led by librarians with experience in either instructing end users, selecting and evaluating software, hardware or vendors, or administration 


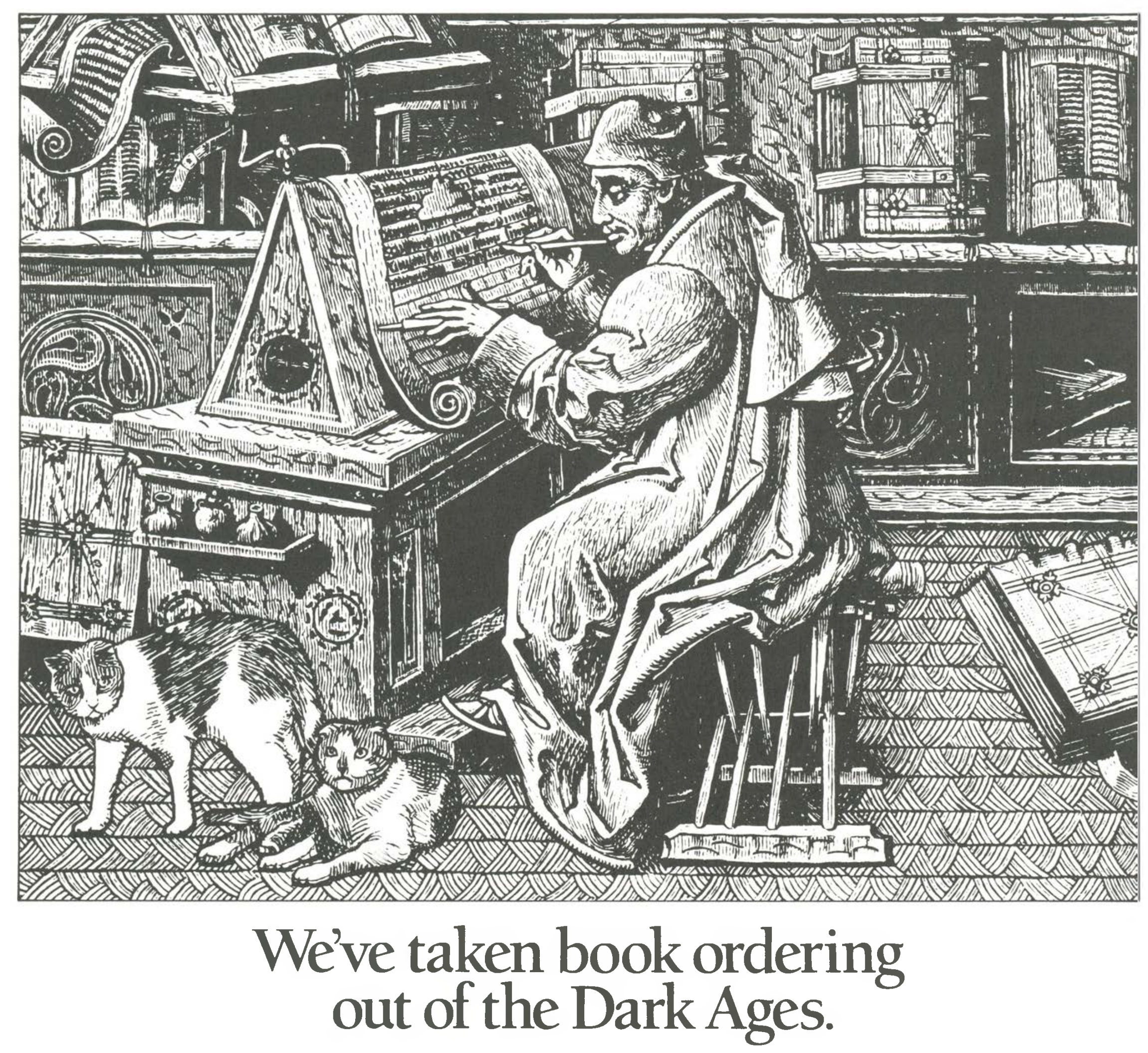

BäTaSYSTEMS ${ }^{\mathrm{TM}}$ is Baker \& Taylor's newest generation of electronic book ordering services. It's especially designed to work with existing computer hardware, with built in flexibility that allows you to match the level of service to your library's unique needs.

Whichever service level you choose, you'll save time, reduce paperwork and speed book acquisitions-all at a lower cost. For example:

ORDER allows you to order books through your personal computer using a modem and regular telephone lines. Just enter the ISBNs and the following day you'll receive electronic confirmation from which you can print order slips. All calls are toll free. You also save the cost and delay of postal delivery.

Or you can choose SEARCH AND ORDER. In addition to electronic ordering, this service gives you quick access to Baker \& Taylor's diverse and comprehensive database of over 800,000 title records. It's your single source for virtually all the titles published or distributed in the United States. And you eliminate manual searching and purchase order typing.

Finally, BaTaSYSTEMS ACQUISITIONS offers on-line access to our database and electronic ordering plus a complete software package with fund accounting and full reporting functions.

These advanced service technologies are typical of how Baker $\&$ Taylor stays in step with the times, building on our experience to bring you the latest in library services.

BaTaSYSTEMS. It's nothing less than a renaissance in book acquisitions.

Write or phone today

for more information.
BAKER \& TAYLOR

a GRACE company 
and funding. Up to 30 small discussion groups will be available for participants to choose from. Brief introductory remarks delineating the major discussion points will be given by Arleen Somerville on instructing end users; Katherine Chiang on selecting and evaluating software, hardware, or vendors; and Gerri Hutchens on administration and funding. The program will be repeated so that participants can attend two different groups. A brief summary of the trends and implications of end user searching will be presented by Bonnie Snow at the end of the program.

\section{Slavic and East European Section}

"Russia and America: Early Relations and Influences" (Monday, June 30, 2:00-4:00 p.m.) will be a panel discussion dealing with the earliest history of library relations between Russia and the United States, 1900-1935. Robert Karlowich of the Pratt Institute will speak on the lengthy trip of H.M. Lydenberg to Soviet Russia in 1923-24; Edward Kasinec, New York Public Library, will discuss the trips of L.B. Khavkina to Russia in 1914 and 1926; N. Zilper, University of North Carolina at Chapel Hill, will deal with the issue of exchanges and sales of library materials from the late 19th century to 1945.

\section{Standards and Accreditation Committee}

"The Revised College Library Standards and the Accreditation Process" (Monday, June 30, 9:00-11:00 a.m.), cosponsored by the ACRL College Libraries Section and the ALA Standards Committee, will address the new College Library Standards (C\&RL News, March 1986, pp. 189-200) and their effect on accreditation and college planning. Speakers will include: David B. Walch, California Polytechnic State University; Patricia A. Sacks, Cedar Crest and Muehlenberg Colleges; Robert Kirkwood, Commission on Higher Education for the Middle States; and Robert J. Wickenheiser, Mount Saint Mary's College.

\section{University Libraries Section}

"University Libraries and Academic Computing Centers: Organizational Roles and Interaction in the 1990's" (Saturday, June 28, 2:00-4:00 p.m.) will focus on how libraries and computing centers will interact in the coming years, whether the two organizations should be merged, what libraries can learn from computing centers and what computing centers can learn from libraries, and what new or changed services will be needed and who should provide them. The speakers will be: Richard L.

\section{Hearing on ACRL's “Model Statement"}

The ACRL Academic Status Committee will hold a hearing at the ALA Annual Conference in New York on proposed revisions to the ACRL "Model Statement of Criteria and Procedures for Appointment, Promotion in Academic Rank, and Tenure for College and University Librarians." The Model Statement was originally issued in 1973 and published in the September and October 1973 issues of College \& Research Libraries News. The hearing will be held on Sunday, June 29, from 8:00-10:00 p.m. in the Beekman Parlor of the New York Hilton Hotel. Copies of the full draft of the proposed revisions will be available at the meeting, or a copy may be obtained by writing to Cathleen Bourdon at the ACRL office, 50 East Huron Street, Chicago, IL 60611.

The revised Model Statement attempts to accomplish two goals. The first is to make editorial changes that are necessary to clarify or amplify points that have been raised since the document was first issued. Second, the revision incorporates a number of changes based upon the 1982 statement by the American Association of University Professors entitled "Recommended Institutional Regulations on Academic Freedom and Tenure," which is published in the 1984 edition of the AAUP manual on Policy Documents \& Reports.
In particular, the proposed revisions to the ACRL Model Statement include sections concerning probationary appointments, imposition of sanctions on faculty members other than dismissal, terminal salary or notice, academic freedom and protection against discrimination, complaints of violation of academic freedom or of discrimination in non-reappointment, treatment of administrative personnel in appointment and promotion, and political activities of faculty members. Extensive revision has also been done in the sections on termination of appointments and dismissal procedures.

The Academic Status Committee is examining the possibility of preparing a separate statement for librarians working at institutions where they are covered by "academic status" rather than "faculty status." The purpose of this hearing, however, will be to examine the proposed revisions in the Model Statement only in light of those institutions where there is "faculty" status.

Further information about the proposed revisions or the hearing may be obtained from the committee chair, Keith Cottam, Director of Libraries, The University of Wyoming, at (307) 766-3279, or write to him at 1167 Inca Drive, Laramie, WY 82070 . 
Van Horn, chancellor, University of HoustonUniversity Park; Raymond Neff, assistant vice chancellor for information systems, University of California, Berkeley; and Richard M. Dougherty, university librarian, University of Michigan.

\section{Western European Specialists Section}

"Research Trends and Library Resources in Western Europe: Assumptions and Realities" (Monday, June 30, 9:30 a.m.-12:30 p.m.) will examine the present and future of European studies and their relation to our national priorities, the needs of scholars conducting European research in North American libraries, and the ability of our libraries to identify and deliver needed resources.
The speakers include: William Bader, SRI International; Ioannis Sinanoglou, Council for European Studies; John Finzi, Library of Congress; A. Gerald Anderson, University of Washington; and Ellen Brow, Harvard University.

The WESS Discussion Group will provide a forum on "Western European Information Services and WESS Librarians: Unrecognized Partners" (Monday, June 30, 2:00-4:00 p.m.). Representatives from the information services of Germany, the Netherlands, Norway, and Sweden will discuss with WESS librarians the services that their agencies provide American academic libraries and ways in which the two groups can increase their cooperation.

\section{ACRL meetings in New York}

\section{A tentative schedule for ALA's New York Conference, June 28-July 3, 1986.}

\section{ACRL BOARD OF DIRECTORS}

First meeting: Saturday, June 28, 2:00-4:00 p.m. Second meeting: Tuesday, July 1, 9:30 a.m.-12:30 p.m.

Executive Committee and Section Officers luncheon: Saturday, June 28, 12:30-2:00 p.m.

\section{ACRL GENERAL}

President's Program/Membership: Monday, June 30, 2:00-5:30 p.m.

\section{ACRL DIVISIONAL COMMITTEES}

Academic Library Statistics: Saturday, June 28, 9:00-11:00 a.m.; Monday, June 30, 9:00-11:00 a.m.

Academic Status: Sunday, June 29, 9:00-11:00 a.m.; Monday, June 30, 9:00-11:00 a.m.; Tuesday, July 1, 2:00-4:00 p.m.

${ }^{*}$ Meetings with an asterisk are closed meetings.
Academic Status_-“Model Statement" Hearing: Sunday, June 29, 8:00-10:00 p.m.

Appointments and Nominations: Saturday, June 28, 2:00-4:00 p.m.; Tuesday, July 1, 9:00-11:00 a.m. ${ }^{*}$

Audiovisual: Saturday, June 28, 8:00-10:00 p.m.; Sunday, June 29, 2:00-5:30 p.m.

Audiovisual-Hearing on Standards: Sunday, June 29, 9:30-11:00 a.m.

Books for College Libraries Advisory: Sunday, June 29, 9:30-11:00 a.m.

Budget and Finance: Friday, June 27, 2:00-5:30 p.m.; Saturday, June 28, 9:00 a.m.-12:30 p.m.; Sundav, June 29, 9:00 a.m.-12:30 p.m., 2:00-5:30 p.m.; Monday, June 30, 9:00 a.m. $-12: 30$ p.m.

Conference Planning: Saturday, June 28, 11:30 a.m. $-12: 30$ p.m.

Continuing Education Courses Advisory: Sunday, June 29, 11:30 a.m.-12:30 p.m.; Monday, June 30, 2:00-4:00 p.m. 